\title{
Do Macroeconomic Variables Predict Deposit Money Banks' Performance in Nigeria
}

\author{
Ejem Chukwu Agwu ${ }^{1, ~}$, Ogbonna Udochukwu Godfrey ${ }^{2}$, Ogbulu Onyemachi Maxwell $^{1}$ \\ ${ }^{1}$ Department of Banking and Finance, Abia State University, Uturu, Nigeria \\ ${ }^{2}$ Department of Management Science, Rhema University, Aba, Nigeria
}

Email address:

ecjah71@yahoo.com (E. C. Agwu)

${ }^{*}$ Corresponding author

\section{To cite this article:}

Ejem Chukwu Agwu, Ogbonna Udochukwu Godfrey, Ogbulu Onyemachi Maxwell. Do Macroeconomic Variables Predict Deposit Money Banks' Performance in Nigeria. International Journal of Accounting, Finance and Risk Management. Vol. 5, No. 3, 2020 , pp. $128-140$. doi: $10.11648 /$ j.ijafrm.20200503.11

Received: May 25, 2020; Accepted: June 8, 2020; Published: June 16, 2020

\begin{abstract}
This study investigated the relationship between macroeconomic variables and the performance of deposit money banks in Nigeria is incited by the heated arguments of finance and economic researchers' on whether macroeconomic variables; Gross Domestic Product rate, interest rate, inflation rate, money supply and exchange rate are or not in control of the banks' management banking sector. Based on that, researchers in this study want to take a solid position on whether macroeconomic variables positively or negatively or of no effect on the performance of deposit money banks (DMBs) in Nigeria. The study made use of suitable finametrica tools to analyze the models. The results of the Error Correction Model and General Method Moments results that all the macroeconomic variables employed (economic growth rate, interest rate, inflation rate, money supply and exchange rate in this study have no significant relationship with bank performance. VECG ranger Causality/Block Exogeneity Wald Test observed that each and jointly, the macroeconomic variables do not cause bank performance both in the short run and long run. Again, impulse response result revealed that bank performance responds insignificantly to the shocks of all the macroeconomic variables. Consequently the researchers advocate that deposit money banks in Nigeria within herent discretionary policy be proactive to the monetary and fiscal policies of regulatory authorities in order to enhance their performance.
\end{abstract}

Keywords: Macroeconomic Variables, ROA, ECM, GMM, VAR

\section{Introduction}

The performance of banks with soaring profits amidst dwindling nature of Nigerian economy has left finance and economic scholars with mix speculations and guess in the recent time. Sometime in the recent past some banks in Nigeria were liquidated, sold or merged as a result of poor performance. As a result, they have been avalanche of studies in economics and finance on whether macroeconomic variables affect the performance of banks and have generated controversies among scholars alike. For instance, in Pakistan, Lutf and Omarkhil [31] in a study impact of macroeconomic determinants and the internal indicators on bank performance with differential effects of macroeconomic variables and bank specific variables. The result found that Gross Domestic
Product, and inflation, is positively related to performance, whereas interest rate has no effect on the performance of banking sector, while, Pradhan and Shrestha [37] in a study impact of bank specific variables and macroeconomic variables on the performance of commercial banks of Nepal. The study tested the impact of importance of bank specific and macro-economic variables on bank performance with regression models. The study found that management efficiency has a very strong and positive relationship with bank performance in Nepal that macroeconomic variables are not significant and hence there is no evidence that external forces have impact over bank performance. Also, Athanasoglous, Brissimis and Delis [9] in Greece investigated the impact of fluctuations in macroeconomic variables on banks' earnings and found that inflation exert positive impact on banks' utility proxied by return on equity 
(ROE) and return on assets (ROA). On another argument on financial crises in the banking sector performance and it's resilience depend on macroeconomic environment, Diamond and Dybvig [17] revealed that if banks' solvency and liquidity ratio decline, macroeconomics shocks, such as great variability of economic growth, exchange rate, or inflation, lead to banking crises and bankruptcy, and therefore requires policymakers interventions in banking system.

On whether Macroeconomic variables such as interest rate has the capacity of expanding or contracting bank lending behaviour through the banking lending channel through the money supply, Alaba [7] suggested that poor macroeconomic performance has the ability of jeopardizing banking deposit mobilization and credit allocation in the economy which can affect negatively the bank performance, while, Akani, Nwana and Mbachu [6] revealed that macroeconomic variables such as interest rate, money supply, inflation, unemployment and exchange rate have direct effect on the performance of the banking sector. Akani et al [6] further opined that the extent to which macroeconomic variables affects banks has a great deal to do with the performance of the banking sector. In addition, Adegbaju, and Olokoyo [4] asserted that macroeconomic shocks, monetary policy schools of thought, political shocks and international liquidity shocks had direct effect on banking sector performance and the well-being of the institutions.

The outcome of a study by Khrawish and Al-Sa'di [28] that macroeconomic variables; GDP growth, interest rate, inflation rate, money supply and exchange rate are not in control of the banks' management has bred policy mixfeelings in the banking sector. Therefore the researchers want to take a position on whether macroeconomic variables such economic growth rate proxied by gross domestic product rate (GDP rate), exchange rates, interest rates and inflation rates positively or negatively or of no effect on the performance of deposit money banks (DMBs) in Nigeria.

The remaining sections of this study are structured as follows; section two takes care of review of literature; section three handles the data and methods; section four analyses the data, results and interpretation while section five is about conclusion and recommendations for policy making, finally section six looks at suggestion for further studies and limitation of the study.

\section{Literature Review}

\subsection{Theoretical Literature}

In economics and finance, theories abound concerning the macroeconomic variables such as economic growth, exchange rate, inflation rate and interest rate theories. The researchers' interest here is to examine studies that applied the respective theories and results relevant to this study.

For instance, Gross Domestic Product in theory, it is revealed that real GDP growth affects positively banking performance through three main channels: net interest income, loan losses improving, and operating costs. That firm profitability increases during economic expansion, and declines in recession periods. Thus, a higher GDP growth causes firms loans and deposits to increase and make bank's net interest income and loans losses to improve. Also, that a higher GDP growth implies higher disposable income, lower unemployment and reduce defaults on consumer loans number. Net interest income and loan losses are therefore pro-cyclical with GDP growth. However, the relation between banks's operating costs and GDP growth is ambiguous [11, 13, 24]. Bolt et al. [11] went further to show that unfavorable economic conditions, such as lower GDP growth rates may decrease deposits and loans and its managing costs as well. These conditions may also possibly raise the costs of collecting payments on loans. It was also found that real GDP has a negative effect on banks' ROA, and a positive effect on $\operatorname{ROE}[2,20,43,44]$.

Revell [38] revealed that Inflation has relationship with banking performance, that 'inflation affects bank's profitability through its effect on overhead costs, in particular salaries and operating costs'. If inflation rate increases, it will lead to a raise in salaries and operating costs, and consequently decrease bank's profitability. Trujillo-Ponce [45] observed that 'if the inflation rate is fully anticipated by the bank's management, the bank can adjust interest rates appropriately to increase revenues faster than costs, which should have a positive impact on profitability'. Studies revealed a mixed findings that show that inflation rate has positive impact on banks' performance because banks manage their costs well under high inflation and a negative and significant relationship between banks' performance, while some revealed found that the inflation does not impact commercial banks' performance [8, 10, 16, 27, 39, 41].

Adler and Dumas [5] revealed 'bank's activities are exposed to exchange rates because asset value volatility depends on the exchange rates'. Exchange rates affect most directly those banks with foreign currency transactions and foreign operations, and even without such activities, exchange rates can affect banks indirectly through their influence on foreign competition, the demand for loans, and other aspects of banking conditions. Adjustment in exchange rate can promote competitiveness of firms since goods manufactured prices at home decline and foreign demand raise. As result increase loans, deposits and banks' profits. It can also reduce domestic consumer purchasing power, as imported goods become more expensive, hence increase loans losses and may have negative effects on bank's performance $[14,30]$. Studies attest to above findings, though with mixed observations; Isaac [23] found 'that unit increases in exchange rate is driven by an increase in profit after tax and equally shows that there is a significant relationship between exchange rate management and performance of financial institutions, most especially banks'. Exchange rate regimes can also exert positive and negative significant or insignificant impact on banks' performance [1, $3,36]$.

Macroeconomics factor like interest rates plays a crucial role in attraction of investors. Without interest rates stability, 
domestic and foreign investors will stay away and resources will be diverted elsewhere. Economic evidence of investment behavior indicates that in addition to conventional factors (past growth of economic activity, real interest rates and private sector credit), private investment is significantly and negatively influenced by uncertainty and macroeconomic instability [40]. Enyioko [19] found that the interest rate policies have not improved the overall performances of banks significantly and also have contributed marginally to the growth of the economy.

\subsection{Empirical Literature}

As earlier stated, plethora of empirical studies tried to resolve the controversial argument on whether macroeconomic variables exert influence on the performance of banks. This study tried to review some the empirical literature; Okoye and Eze [34] used regression analysis looked at the impact of bank lending rate on the performance of Nigerian Deposit Money Banks found that the lending rate and monetary policy rate have significant and positive effects on the performance of Nigerian deposit money banks.

Applying Pooled Ordinary least method, Osamwonyi and Michael [35] examined the impact of macroeconomic variables on profitability of banks in Nigeria. The study engaged three macroeconomic variables (gross domestic product, interest rate and inflation (INFR) with return on equity (ROE) as proxy for profitability. It was found that a positive relationship exist between gross domestic product and return on equity, while interest rate and inflation rate have a negative relationship with return on equity

Akani, Nwana and Mbachu [6] investigated the effects of selected macroeconomic variables on Commercial Banks performance in Nigeria with the aim of unraveling the effects of selected macroeconomic shocks (Inflation rate, real gross domestic product, Real interest rate, Exchange rate, Broad Money Supply and unemployment Rate) on the performance of Nigerian banks (Return on Assets and Return on Equity). The employed three multiple regressions models, Johansen co-integration test, Unit Root test, Vector Error (VECM) and Granger Causality tests. The results revealed that inflation rate, Real Gross Domestic Product, Exchange Rate, Broad money supply, interest rate and unemployment rate exert insignificant effects on Return on Assets and Return on Equity. The overall result found that there is a positive and significant relationship between selected macroeconomic variables and Commercial Banks performance in Nigeria.

Combey and Togbenou [15] used Pool Mean Group estimator to examine short-run and long-run relationship between three main macroeconomic indicators (gross domestic product growth, real effective exchange rate, and inflation) and banking sector profitability (return on assets and return on equity). The output indicated that, in the shortrun, banks' return on assets and return on equity are not related to macroeconomic variables, while banks' return on assets is determined positively by bank capital to assets ratio and bank size while banks' return on equity is affected negatively by bank capital to assets ratio. In the long-run, real gross domestic product growth and real effective exchange rate were found to have negative and significant impact on banks' return on assets, while inflation rate has no significant effect. On bank's return on equity, in the long-run, results revealed that real gross domestic product growth, real effective exchange rate, and inflation exert negative impact on bank's return on equity.

\section{Methodology}

\subsection{Data and Method}

This study employed data that spanned from 1989 to 2018 collected from Nigerian Deposit Insurance Cooperation (NDIC), Central Bank of Nigeria (CBN) and National Bureau of Statistics (NBS). The variables represented in the collected data are macroeconomic variables; Economic Growth rate (GDPR), Exchange Rate (EXCR), Inflation Rate (INFLR) and Interest Rate (INTR) and Bank Performance (Return on Assets). The choice of these macroeconomic variables is because of the belief that 'interest rate, exchange rate, inflation rate and GDP are the most important among macroeconomic variables which affect the performance of a financial superstructure [22]. Also, Return on Assets (ROA) has proven to be main and one important ratio or indicator for measurement of bank performance [9, 15, 35].

To check the stationarity of the variables, the Augmented Dickey Fuller (ADF) unit root test is used, to determine if long run relationship exists between the dependent and independent variables in this study, Johansen Cointegration is used. In testing for multicollinearity and global utility of specified models, the correlation matrix and ordinary least square (OLS) are engaged. To examine the interplay of the long run and short term fluctuations in the model, error correction model (ECM) is used. Because of the dynamic nature of the variables both Vector Autoregressive (VAR) and Generalized Method of Moments (GMM) were employed in testing the models.

\subsection{Description of Tools}

\subsubsection{Unit Root Test}

To stem the problem of spurious regression, it is important that the time series properties of the data set employed in the estimation is ascertained. It might be reasonable to test for the presence of unit root in the series using the Augmented Dickey Fuller (ADF) unit root test to test for the stationarity of the variables [12]. Unit root tests are tests for stationary in a time series. A time series has stationarity if a shift in time doesn't cause a change in the shape of the distribution; unit roots are one cause for non-stationarity. The ADF handles bigger, more complex models. It does have the downside of a fairly high Type I error rate.

Deriving from AR (p) representation, the ADF test involves the following regressions:

$$
\begin{aligned}
& \text { No constant, no trend: } \Delta \mathrm{y}_{\mathrm{t}}=\gamma \mathrm{y}_{\mathrm{t}-1}+v_{\mathrm{t}} \\
& \text { Constant, no trend: } \Delta \mathrm{y}_{\mathrm{t}}=\alpha+\gamma \mathrm{y}_{\mathrm{t}-1}+v_{\mathrm{t}}
\end{aligned}
$$




$$
\text { Constant and trend: } \Delta \mathrm{y}_{\mathrm{t}}=\alpha+\gamma \mathrm{y}_{\mathrm{t}-1}+\lambda_{\mathrm{t}}+v_{\mathrm{t}}
$$

these models:

The Augmented Dickey Fuller adds lagged differences to

$$
\begin{gathered}
\text { Non const } \backslash \text { ant, no trend: } \Delta y_{t}=\gamma y_{t-1}+\sum_{S=1}^{m} a_{s} \Delta y_{t-s}+v_{t} \\
\text { Constant, no trend: } \Delta y_{t}=\alpha+\gamma y_{t-1}+\sum_{S=1}^{m} a_{s} \Delta y_{t-s}+v_{t} \\
\text { Constant and trend: } \Delta y_{t}=\alpha+\gamma y_{t-1}+\lambda_{t}+\sum_{S=1}^{m} a_{s} \Delta y_{t-s}+v_{t}
\end{gathered}
$$

Let $\gamma_{\mathrm{t}}$ be a time series.

\subsubsection{Co-integration Test}

It is often said that co-integration is a means for correctly testing the relationship between two variables having unit roots (integrated order 1). The Johansen's co-integration test was applied to check the co-integration between and among the variables. There are different methods of testing for cointegration but Jung and Seldon [26] stated that Johansen cointegration test is more valid as there is no need of prior knowledge of the co-integration vectors in cases when they are unknown. According to Koirala [29], the Johansen [25] method of testing for the existence of co-integration relationships has become standard in the econometrics literature because of its superiority over other alternatives. According to Engle and Granger [18], as a set of variables Yt is said to be co-integrated of order $(\mathrm{d}, \mathrm{b})$ denoted $\mathrm{Yt}=\mathrm{CI}(\mathrm{d}, \mathrm{b})$ if all components of $\mathrm{Yt}$ are integrated of order $\mathrm{d}$ or $\mathrm{b}$ (band $\mathrm{d}>$ $0)$ and there exists a vector $\beta=\left(\beta_{1}, \beta_{2} \ldots \beta_{\mathrm{n}}\right)$ such that a linear combination $\beta \mathrm{Y}_{\mathrm{t}}=\beta_{1} \mathrm{Y}_{1 \mathrm{t}}+\beta_{2} \mathrm{Y}_{2 \mathrm{t}}+\ldots \ldots \beta_{\mathrm{n}} \mathrm{Y}_{\mathrm{nt}}$ is not integrated of $\operatorname{order}(\mathrm{d}, \mathrm{b})$.

\subsubsection{Error Correction Mechanism (ECM)}

The next step is to estimate the equation using ordinary least square (OLS) technique. Having ascertained whether or not co-integration exist, then the next step requires the construction of error correction mechanism to model dynamics relationship. The purpose of the error correction model is to indicate the speed of adjustment from the shortrun equilibrium to the long-run equilibrium state. If cointegration is accepted, it suggests that the model is best specified in the first difference of its variables with one period lag of the residual $\{\mathrm{ECM}(-1)\}$ as an additional regressor. The advantage of using error correction models (ECM) is that it incorporates the variables at both side levels and first differences and thus ECM captures the short run disequilibrium situations as well as the long-run equilibrium adjustments between variables [33]. Co-integration is a test for equilibrium between non-stationary variables integrated of the same order.

\subsubsection{Vector Autoregressive Models}

Vector autoregressive models (VARs) were popularized in econometrics by Sims in 1980 as a natural generalization of univariate autoregressive model. A VAR is a system regression model (i.e. there is more than one dependant variable) that can be considered a kind of hybrid between the univariate time series models and the simultaneous equations models. VARs have often been advocated as an alternative to large-scale simultaneous equations structured medels [12].

\subsubsection{Granger Causality Test}

The Granger causality test is a statistical hypothesis test for determining whether one time series is useful in forecasting another while ordinary regression reflects mere correlations. Granger causality in economics could be tested for by measuring the ability to predict the future values of a time series using prior values of another time series. To determine the direction of causality between the variables, we employ the standard Granger causality test [21]. The test is based on error correction (ECM), which suggests that while the past can cause or predict the future, the future cannot predict or cause the past. Thus, according to Granger [21], X Granger causes $Y$ if past values of X can be used to predict $Y$ more accurately than simply using the past values of $\mathrm{Y}$. If a time series is a stationary process, the test is performed using the level values of two (or more) variables. In practice it may be found that neither variable Grangercauses the other, or that each of the two variables Grangercauses the other. For instance, if a signal $\mathrm{X}_{1}$ "Grangercauses" (or "G-causes") a signal $\mathrm{X}_{2}$, then past values of $\mathrm{X}_{1}$ should contain information that helps predict $\mathrm{X}_{2}$ above and beyond the information contained in past values of $\mathrm{X}_{2}$ alone. The test is based on the following regressions:

$$
\begin{gathered}
\mathrm{Y}_{\mathrm{t}}=\alpha_{0}+\sum_{-}(i=1)^{\wedge} n \alpha_{\mathrm{i}}{ }^{\mathrm{y}} \mathrm{Yt}_{-1} \sum_{i=1}^{n} \mathrm{Xt}-1 \alpha_{\mathrm{i}} \mathrm{x}+\mathrm{U}_{\mathrm{t}} \\
\mathrm{X}_{\mathrm{t}}=\beta_{0}+\sum_{-}(i=1)^{\wedge} n \beta_{\mathrm{i}}{ }^{\mathrm{y}} \mathrm{Yt}_{-1} \sum_{i=1}^{n} \mathrm{Xt}-\mathrm{k} \beta_{\mathrm{i}} \mathrm{x}+\mathrm{Y}_{\mathrm{t}}
\end{gathered}
$$

Where $X_{t}$ and $Y_{t}$ are the variables to be tested while $U_{t}$ and $\mathrm{V}_{\mathrm{t}}$ are white noise disturbance terms. The null hypothesis $\alpha_{\mathrm{i}}$ ${ }^{\mathrm{x}}=\beta_{\mathrm{i}}{ }^{\mathrm{y}}=0$ for all i's is tested against the alternative hypothesis $\alpha_{\mathrm{i}}{ }^{\mathrm{x}} \neq 0$ and $\beta_{\mathrm{i}}{ }^{\mathrm{y}}=0$. If the co-efficient of $\alpha_{\mathrm{i}}{ }^{\mathrm{x}}$ are statistically significant but that of $\beta_{\mathrm{i}}{ }^{\mathrm{y}}$ are not, then $\mathrm{X}$ causes $\mathrm{Y}$. If the reverse is true, then $\mathrm{Y}$ causes $\mathrm{X}$. However, where both coefficient of $\alpha_{\mathrm{i}}{ }^{\mathrm{x}}$ and $\beta_{\mathrm{i}}{ }^{\mathrm{y}}$ are significant then causality is bi- directional.

\subsubsection{Impulse Responses and Variance Decomposition}

Block F-tests and examination causality in a VAR will suggest which of the variables in the model has statically significant impact on the future values of each of the variables in the system. But F-test results will not, by 
construction is able to explain the sign of the relationship or how long these effects require to take place. That is, F-test results will not reveal whether changes in the value of a given variable have a positive or negative effect on other variables in the system, or how long it would take for the effect of that variable to work through the system. Such information will, however, be given by an examination of the VAR's impulse responses and variance decompositions [12].

Impulse responses trace out the responsiveness of the dependent variables in the VAR to shocks to each of the variables. So, for each variable from each equation separately, a unit shock is applied to the error, and the effects upon the VAR system over time are noted. Thus, if there are $\mathrm{g}$ variables in a system, a total of $\mathrm{g}^{2}$ impulse responses could be generated. The way that this is achieved in practice is by expressing the VAR model as a NMA- that is, the vector autoregressive model written as a vector moving average (in the same way as was done for univariate autoregressive models in previous case). Provided that the system is stable, the shock should gradually die away [12].

Variance decompositions offer a slightly different method for examining VAR system dynamics. They give the proportion of the movements in the dependent variables that are due to their 'own' shocks, versus shocks to the other variables. A shock to the $i^{\text {th }}$ variable will directly affect that variable of course, but it will also be transmitted to all of the other variables in the system through the dynamic structure of the VAR. Variance decomposition determine how much the $s$-step-ahead forecast error variance of a given variable is explained by innovations to each explanatory variable for $\mathrm{s}=1$, $2, \ldots$ In practice, it is usually observed that own series shocks explain most of the (forecast) error variance of the series in a VAR. To some extent, impulse responses and variance decompositions offer very similar information [12].

For calculating impulse responses and variance decompositions, the ordering of the variables is important. To see why this is the case, recall that the impulse responses refer to a unit shock to the errors of one VAR equation alone. This implies that the error terms of all other equations in the VAR system are held constant. However, this is not realistic since the error terms are likely to be correlated across equations to some extent. Thus, assuming that they are completely independent would lead to a misrepresentation of the system dynamics. In practice, the errors will have a common component that cannot be associated with a single variable alone [12].

\subsubsection{Generalized Method of Moments (GMM)}

In econometrics and statistics, the generalized method of moments (GMM) is a generic method for estimating parameters in statistical models. Usually it is applied in the context of semi parametric models, where the parameter of interest is finite-dimensional, whereas the full shape of the data's distribution function may not be known, and therefore maximum likelihood estimation is not applicable. The method requires that a certain number of moment conditions were specified for the model. These moment conditions are functions of the model parameters and the data, such that their expectation is zero at the parameters' true values. The GMM method then minimizes a certain norm of the sample averages of the moment conditions. The GMM estimators are known to be consistent, asymptotically normal, and efficient in the class of all estimators that do not use any extra information aside from that contained in the moment conditions. GMM was developed by Lars Peter Hansen in 1982 as a generalization of the method of moments, [1] introduced by Karl Pearson in 1894. Hansen shared the 2013 Nobel Prize in Economics in part for this work [46].

\subsection{Model Specification}

Starting from the functional form;

Return on Assets $=\mathrm{f}$ (Macroeconomic Variables)

Return on Assets=f (Economic Growth Rates, Exchange Rates, Inflation Rates, Interest Rate)

$\mathrm{ROA}=\mathrm{f}(\mathrm{GDPR}, \mathrm{EXCR}, \mathrm{INFLR}$ and INTR)

Then, the explicit form;

The reduced VAR model, incorporating Return on Assets (ROA), Economic Growth Rates (GDPR), Exchange Rates (EXCR), Inflation Rates (INFLR), and Interest Rate (INTR) is stated as below;

$$
\begin{aligned}
& \mathrm{ROA}_{\mathrm{t}}=\alpha_{01}+\alpha_{11} \mathrm{ROA}_{\mathrm{t}-1}+\alpha_{21} \mathrm{GDPR}_{\mathrm{t}-1}+\alpha_{31} \mathrm{EXCR}_{\mathrm{t}-1}+\alpha_{41} \mathrm{INFLR}_{\mathrm{t}-1}+\alpha_{51} \mathrm{INTR}_{\mathrm{t}-1}+\mathrm{U}_{\mathrm{t} 1} \\
& \operatorname{GDPR}_{\mathrm{t}}=\beta_{02}+\beta_{12} \mathrm{ROA}_{\mathrm{t}-1}+\beta_{22} \text { GDPR }_{\mathrm{t}-1}+\beta_{32} \mathrm{EXCR}_{\mathrm{t}-1}+\beta_{42} \text { INFLR }_{\mathrm{t}-1}++\beta_{52} \text { INTR }_{\mathrm{t}-1}+\mathrm{U}_{\mathrm{t} 2} \\
& \mathrm{EXCR}_{\mathrm{t}}=\gamma_{03}+\gamma_{13} \mathrm{ROA}_{\mathrm{t}-1}+\gamma_{23} \text { GDPR }_{\mathrm{t}-1}+\gamma_{33} \mathrm{EXCR}_{\mathrm{t}-1}+\gamma_{43} \text { INFLR }_{\mathrm{t}-1}+\gamma_{53} \mathrm{INTR}_{\mathrm{t}-1}+\mathrm{U}_{\mathrm{t} 3} \\
& \mathrm{INFLR}_{\mathrm{t}}=\mathrm{Z}_{04}+\mathrm{Z}_{14} \mathrm{ROA}_{\mathrm{t}-1}+\mathrm{Z}_{24} \mathrm{GDPR}_{\mathrm{t}-1}+\mathrm{Z}_{34} \mathrm{EXCR}_{\mathrm{t}-1}+\mathrm{Z}_{44} \mathrm{INFLR}_{\mathrm{t}-1}++\mathrm{Z}_{54} \mathrm{INTR}_{\mathrm{t}-1}+\mathrm{U}_{\mathrm{t} 4} \\
& \mathrm{INTR}_{\mathrm{t}}=\partial_{05}+\partial_{15} \mathrm{ROA}_{\mathrm{t}-1}+\partial_{25} \mathrm{GDPR}_{\mathrm{t}-1}+\partial_{35} \mathrm{EXCR}_{\mathrm{t}-1}+\partial_{45} \mathrm{INFLR}_{\mathrm{t}-1}+\partial_{55} \mathrm{INTR}_{\mathrm{t}-1}+\mathrm{U}_{\mathrm{t} 5}
\end{aligned}
$$

While the GMM explicit form in first difference is;

$$
\mathrm{ROA}=\mathrm{b}_{0}+\mathrm{b}_{1} \mathrm{ROA}_{\mathrm{t}-1}+\mathrm{b}_{2} \mathrm{GDPR}+\mathrm{b}_{3} \mathrm{GDPR}_{\mathrm{t}-1}+\mathrm{b}_{4} \mathrm{EXCR}+\mathrm{b}_{5} \mathrm{EXCR}_{\mathrm{t}-1}+\mathrm{b}_{6} \mathrm{INFLR}+\mathrm{b}_{7} \text { INFLR }_{\mathrm{t}-1}+\mathrm{b}_{8} \mathrm{INTR}+\mathrm{b}_{9} \mathrm{INTR}_{\mathrm{t}-1}+\mathrm{e}_{\mathrm{t}-1}
$$


Where $U_{t}$ are white noises that capture the innovations or shocks to the VAR system.

And final, the Operational form (Apriori Expectation);

$\alpha_{1}, \alpha_{2}, \alpha_{3}$ and $\alpha_{4}>0<0$, are coefficient of GDPR, EXCR, INFLR and INTR. It is expected that macroeconomic variables will either positively or negatively influence deposit money banks' performance.

\section{Analysis and Discussion}

ROA

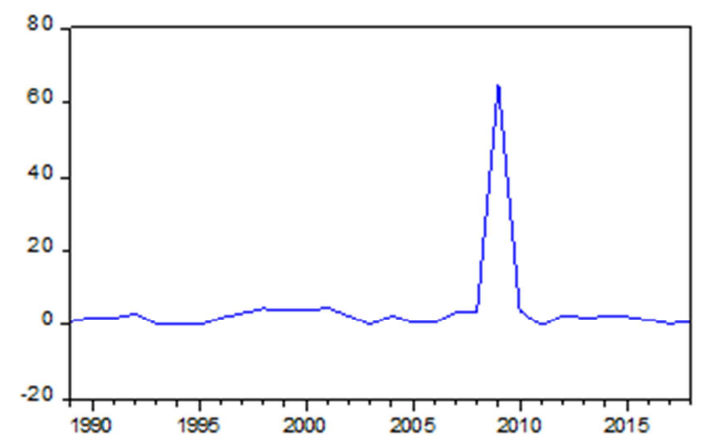

EXCR

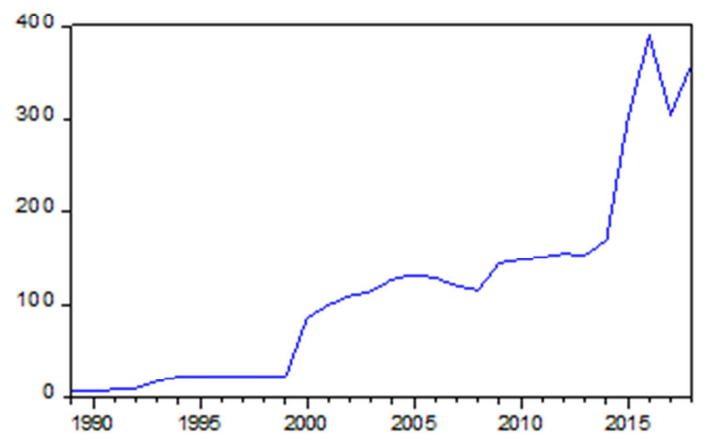

INTR

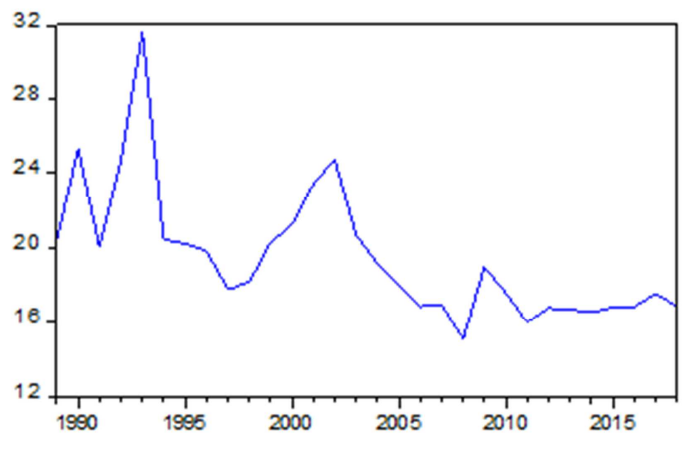

First, the time series plot of the data is shown in figure 1 below,

The figure below shows that all trended upward and downward, sometimes undulation over the period of the study, indicating non-stationarity of the variables as expected, except ROA that recorded a sharp trend upward from 2008 to 2010, which is not violent fluctuation. In all the variables there are periods of troughs and peaks. It can be recognize as outliers in the years.
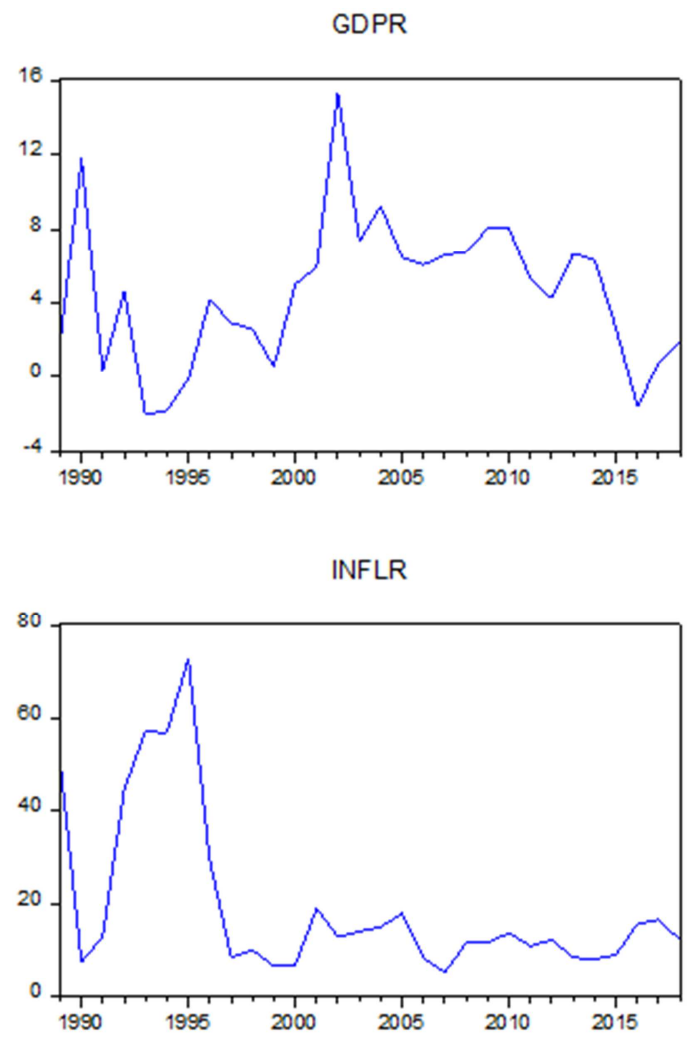

Figure 1. The time series of ROA, GDPR, EXCR, INFLR and INTR.

The researchers continued with the description of the variables as shown below;

Table 1 below shows the summary of statistics that describe the distributional features of all the data. The variables recorded average of the following; $4.24 \%, 4.53 \%$, $116.3 \%, 19.5 \%$ and $19.5 \%$ for ROA, GDPR, EXCR, INFLR and INTR respectively. This shows exchange rate fluctuates more than other macroeconomic variables, while economic growth rate is the least. The risk (standard deviation) inherent in each of the monetary policy variables are 11.5, 3.9, 105.7, 17.8 and 3.5 for ROA, GDPR, EXCR, INFLR and INTR respectively. These also suggest that exchange rate is the 
most volatile with economic growth rate again recording the least. ROA, EXCR, INFLR and INTR showed Kurtosis greater than 3, suggesting a leptokurtic distribution, while GDPR is close to 3 suggesting mesokurtic or symmetric or normal distribution. Jarque-Bera normality distribution test statistic probability values show that ROA, EXCR, INFLR and INTR have abnormal distribution while GDPR is normally distributed.

\subsection{Descriptive Statistics}

Table 1. Descriptive Statistics of ROA, GDPR, EXCR, INFLR and INTR.

\begin{tabular}{|c|c|c|c|c|c|}
\hline & ROA & GDPR & EXCR & INFLR & INTR \\
\hline Mean & 4.240333 & 4.537210 & 116.3640 & 19.52686 & 19.53767 \\
\hline Median & 2.225000 & 4.823550 & 114.7500 & 12.54720 & 18.58500 \\
\hline Maximum & 64.92000 & 15.32920 & 390.0000 & 72.83550 & 31.65000 \\
\hline Minimum & -0.040000 & -2.035100 & 7.390000 & 5.382200 & 15.14000 \\
\hline Std. Dev. & 11.55258 & 3.992481 & 105.7699 & 17.84150 & 3.542828 \\
\hline Skewness & 5.067681 & 0.432436 & 1.101552 & 1.752831 & 1.580807 \\
\hline Kurtosis & 27.15536 & 3.300308 & 3.615834 & 4.789881 & 5.747999 \\
\hline Probability & 0.000000 & 0.592226 & 0.037985 & 0.000062 & 0.000017 \\
\hline Sum & 127.2100 & 136.1163 & 3490.920 & 585.8058 & 586.1300 \\
\hline Sum Sq. Dev. & 3870.404 & 462.2572 & 324431.0 & 9231.249 & 363.9973 \\
\hline Observations & 30 & 30 & 30 & 30 & 30 \\
\hline
\end{tabular}

\subsection{Global Utility Test}

In the macroeconomic analysis, it is pertinent to check the global utility or usefulness of the specified models. To achieve this, the researchers engaged correlation matrix and ordinary least square.

\subsection{Multicollinearity Test}

Table 2 below shows the summary of correlation of the variables. The correlations between ROA, GDPR, EXCR, INFLR and INTR range from -0.509641 to 0.477304 indicating that the variables are not linearly correlated. Therefore, the researchers have enough evidence to announce no presence of multicollinearity in the model.

Table 2. Correlation Matrix.

\begin{tabular}{|c|c|c|c|c|c|}
\hline Variables & ROA & GDPR & EXCR & INFLR & INTR \\
\hline ROA & 1.000000 & 0.200365 & 0.027265 & -0.139417 & -0.033571 \\
\hline GDPR & 0.200365 & 1.000000 & -0.051153 & -0.480146 & 0.017902 \\
\hline EXCR & 0.027265 & -0.051153 & 1.000000 & -0.388213 & -0.509641 \\
\hline INFLR & -0.139417 & -0.480146 & -0.388213 & 1.000000 & 0.477304 \\
\hline INTR & -0.033571 & 0.017902 & -0.509641 & 0.477304 & 1.000000 \\
\hline
\end{tabular}

Again, Table 3 below depicts the Ordinary Least Square (OLS) estimated model for the relationship between macroeconomic variables and performance of deposit money banks. From the table Durbin-Watson statistics is 2.033800, showing no absence of autocorrelation. But F-statistic value is 0.280031 with p-value of 0.8888104 showing that null hypothesis cannot be rejected; there is overall insignificance and invalid for comparison. Therefore cannot be used for further analysis and policy formulation.

Table 3. Ordinary Least Square (OLS) Methods.

\begin{tabular}{llll}
\hline Variable & Coefficient & Std. Error & t-Statistic \\
\hline GDPR & 0.523797 & 0.694126 & 0.754614 \\
EXCR & 0.001717 & 0.025782 & 0.066582 \\
INFLR & -0.027381 & 0.179860 & -0.152234 \\
INTR & -0.028105 & 0.814556 & -0.034503 \\
C & 2.747768 & 16.56009 & 0.165927 \\
R-squared & 0.042884 & Mean dependent var & 0.8475 \\
Adjusted R-squared & -0.110255 & S. D. dependent var & 0.9728 \\
S. E. of regression & 12.17280 & Akaike info criterion & 0.8695 \\
Sum squared resid & 3704.427 & Schwarz criterion & 4.240333 \\
Log likelihood & -114.8095 & Hannan-Quinn criter. & \\
F-statistic & 0.280031 & Durbin-Watson stat & \\
Prob (F-statistic) & 0.888104 & & 8.987297 \\
\hline
\end{tabular}

Dependent Variable: ROA.

Method: Least Squares. 


\subsection{Stationarity/Unit Root Test}

This is statistical valid procedure in macroeconomics time series analysis that assists to determining the best estimation method for the data. It is due to the peculiarities of time series data. To do this the popular Augmented Dickey Fuller (ADF) unit root/stationary test is used as shown below. Table 4 below reveals the summary of stationary test for both level and first difference data. The results indicates that ROA and GDPR are integrated at level and order one, but ADF test statistic coefficient are more negative than critical values at $5 \%$ and $10 \%$ at first difference than at level, while EXCR, INFLR and INTR are all integrated at order one. In sum, all the variables are differenced once to be stationary at $5 \%$ and $10 \%$.

Table 4. Augmented Dickey Fuller Unit Root Test.

\begin{tabular}{|c|c|c|c|c|c|c|c|c|}
\hline \multirow{3}{*}{ Variables } & \multirow{3}{*}{$\begin{array}{l}\text { SCIL } \\
\text { ag }\end{array}$} & \multicolumn{3}{|l|}{ LEVEL } & \multicolumn{3}{|l|}{$1^{\text {st }}$ DIFFERENCE } & \multirow{3}{*}{ Remark } \\
\hline & & \multirow{2}{*}{ ADF Stat/Prob. } & \multicolumn{2}{|c|}{ Critical Values } & \multirow{2}{*}{ ADF Stat/Prob. } & \multicolumn{2}{|c|}{ Critical Values } & \\
\hline & & & $5 \%$ & $10 \%$ & & $5 \%$ & $10 \%$ & \\
\hline ROA & 7 & $-5.059096(0.0003)$ & -2.967767 & -2.622989 & $-8.417883(0.0000)$ & -2.971853 & -2.625121 & @1 (1) \\
\hline GDPR & 7 & $-3.449617(0.0172)$ & -2.967767 & -2.622989 & $-9.910660(0.0000)$ & -2.971853 & -2.625121 & @1 (1) \\
\hline LnEXCR & 7 & $-1.180496(0.6690)$ & -2.967767 & -2.622989 & $-4.953202(0.0004)$ & -2.971853 & -2.625121 & @1 (1) \\
\hline LnINFLR & 7 & $-2.531245(0.1192)$ & -2.971853 & -2.625121 & $-6.145984(0.0000)$ & -2.971853 & -2.625121 & @1 (1) \\
\hline LnINTR & 7 & $-2.382235(0.1552)$ & -2.967767 & -2.622989 & $-2.622989(0.0000)$ & -2.971853 & -2.625121 & @ 1 (1) \\
\hline
\end{tabular}

\subsection{Cointegration and Long Run Relationship Test}

This is necessary to know if there exist equilibrium relationships between the variables; ROA, GDPR, EXCR, INFLR and INTR as shown below; Table 5 below shows that unrestricted rank tests (Trace and Maximum Eigenvalue) have trace statistics of $124.78811,63.34527$, and 32.10045 with probability values of $0.0000,0.0009, \quad 0.0267$ respectively and Max-Eigen Statistica of 61.43585, 31.24482, and 21.50998 with p-values of $0.0000,0.0009,0.0267$ respectively at 'None', At most 1 and At most 2 hypotheses. That shows three cointegration equations at $5 \%$ level of significance among the variables. This is sufficient evidence to show that long run relationship exists between the dependent variable bank performance proxied by ROA and independent variables; macroeconomic variables (GDPR, EXCR, INFLR and INTR).

Table 5. Johansen Cointegration Test.

\begin{tabular}{|c|c|c|c|c|}
\hline \multicolumn{5}{|c|}{ Unrestricted Cointegration Rank Test (Trace) } \\
\hline Hypothesized & & Trace & 0.05 & \\
\hline No. of CE (s) & Eigenvalue & Statistic & Critical Value & Prob.** \\
\hline None * & 0.973053 & 124.7811 & 69.81889 & 0.0000 \\
\hline At most $1 *$ & 0.840854 & 63.34527 & 47.85613 & 0.0009 \\
\hline At most $2 *$ & 0.717843 & 32.10045 & 29.79707 & 0.0267 \\
\hline At most 3 & 0.454695 & 10.59047 & 15.49471 & 0.2380 \\
\hline At most 4 & 0.016422 & 0.281500 & 3.841466 & 0.5957 \\
\hline
\end{tabular}

*** Trace test indicates 3 cointegrating eqn (s) at the 0.05 level.

\begin{tabular}{|c|c|c|c|c|}
\hline \multicolumn{5}{|c|}{ Unrestricted Cointegration Rank Test (Maximum Eigenvalue) } \\
\hline Hypothesized & & Max-Eigen & 0.05 & \\
\hline No. of CE (s) & Eigenvalue & Statistic & Critical Value & Prob.** \\
\hline None * & 0.973053 & 61.43585 & 33.87687 & 0.0000 \\
\hline At most $1 *$ & 0.840854 & 31.24482 & 27.58434 & 0.0161 \\
\hline At most $2 *$ & 0.717843 & 21.50998 & 21.13162 & 0.0442 \\
\hline At most 3 & 0.454695 & 10.30897 & 14.26460 & 0.1924 \\
\hline At most 4 & 0.016422 & 0.281500 & 3.841466 & 0.5957 \\
\hline
\end{tabular}

*** Max-eigenvalue test indicates 3 cointegrating eqn (s) at the 0.05 level.

\subsection{Contemporaneous Relationship Between ROA, GDPR, EXCR, INFLR and INTR}

It can be recalled that OLS exhibits unsatisfactory global utility, and was therefore abandoned. For that the researchers moved ahead to determine the relationship between performance of deposit money banks and macroeconomic variables with Error Correction Mechanism (ECM) and
General Method Moments (GMM).

\subsubsection{Error Correction Mechanism (ECM)}

The cointegration test result provides for short run fluctuations. Therefore, the researchers apply error correction model to examine the interplay of the long run and short term fluctuations in the model using the general specific approach.

The results in Table 6 below show that are the variables; 
GDPR, EXCR, INFLR and INTR at all lags insignificantly relate to ROA. It was also found that the independent variables (GDPR, EXCR, INFLR and INTR) only explained $14.8 \%$ of total variation in the dependent variable (ROA). That shows that macroeconomic variables are not enough to explain the variations in the bank performance (ROA). It is also good to know that autocorrelation issue should not be bordered in this model with Durbin-Watson Statistic of 2.360058 .

Table 6. Parsimonious ECM.

\begin{tabular}{lllll}
\hline \multicolumn{2}{l}{ Dependent Variable: D (LNROA) } \\
\hline Variable & Coefficient & Std. Error & t-Statistic & Prob. \\
\hline D (LNROA (-1)) & -0.766528 & 0.864748 & -0.886418 & 0.4048 \\
D (LNGDPR (-1)) & 0.302243 & 0.522708 & 0.578225 & 0.5812 \\
D (LNGDPR (-2)) & -0.180349 & 1.083428 & -0.166462 & 0.8725 \\
D (LNEXCR (-1)) & -0.518780 & 1.432473 & -0.362157 & 0.7279 \\
D (LNEXCR (-2)) & 0.804709 & 2.935330 & 0.274146 & 0.7919 \\
D (LNINFLR (-1)) & -0.897549 & 1.643886 & -0.545992 & 0.6020 \\
D (LNINFLR (-2)) & -0.765617 & 0.798353 & -0.958995 & 0.3695 \\
D (LNINTR (-1)) & -10.48177 & 12.20076 & -0.859108 & 0.4187 \\
D (LNINTR (-2)) & -2.900602 & 6.431987 & -0.450965 & 0.6657 \\
\hline
\end{tabular}

\begin{tabular}{lllll}
\hline \multicolumn{4}{l}{ Dependent Variable: D (LNROA) } & \\
\hline Variable & Coefficient & Std. Error & t-Statistic & Prob. \\
\hline ECM (-1) & 0.604430 & 1.476291 & 0.409425 & 0.6945 \\
R-squared & 0.627679 & Mean dependent var & -0.125468 \\
Adjusted R-squared & 0.148980 & S. D. dependent var & 1.556411 \\
S. E. of regression & 1.435800 & Akaike info criterion & 3.850489 \\
Sum squared resid & 14.43065 & Schwarz criterion & 4.340615 \\
Log likelihood & -22.72916 & Hannan-Quinn criter. & 3.899209 \\
Durbin-Watson stat & 2.360058 & & \\
\hline
\end{tabular}

\subsubsection{General Methods Moment}

Due to the dynamic nature of the variables, the researchers also adopted the General Method Moments (GMM). Table 7 reveals the estimation of the model using Generalized Method of Moments (GMM). J-statistic has coefficient of 5.811376 with probability value of 0.213685 , which shows the model is significant and suitable to adduce the Contemporaneous Relationship between ROA, GDPR, EXCR, INFLR and INTR. Table 7 also reveals that show that are the macroeconomic variables; GDPR, EXCR, INFLR and INTR have no significant relationship with to ROA.

Table 7. General Methods Moment.

\begin{tabular}{|c|c|c|c|c|}
\hline \multicolumn{5}{|c|}{ Dependent Variable: LNROA } \\
\hline \multicolumn{5}{|c|}{ Method: Generalized Method of Moments } \\
\hline \multicolumn{5}{|c|}{ Instrument specification: LNGDPR LNGDPR (-1) LNEXCR LNEXCR (-1) } \\
\hline \multicolumn{5}{|c|}{ LNINFLR LNINFLR (-1) LNINTR LNINTR (-1) } \\
\hline \multicolumn{5}{|c|}{ Constant added to instrument list } \\
\hline Variable & Coefficient & Std. Error & t-Statistic & Prob. \\
\hline LNGDPR & 0.068524 & 0.117399 & 0.583688 & 0.5671 \\
\hline LNEXCR & -0.116690 & 0.176298 & -0.661891 & 0.5169 \\
\hline LNINTR & -0.096854 & 1.064353 & -0.090998 & 0.9286 \\
\hline $\mathrm{C}$ & 1.958956 & 3.391315 & 0.577639 & 0.5711 \\
\hline R-squared & 0.018233 & Mean dependent var & & 0.938247 \\
\hline Adjusted R-squared & -0.212771 & S. D. dependent var & & 1.061281 \\
\hline S. E. of regression & 1.168744 & Sum squared resid & & 23.22138 \\
\hline Durbin-Watson stat & 1.720523 & J-statistic & & 5.811376 \\
\hline Instrument rank & 9 & Prob (J-statistic) & & 0.213685 \\
\hline
\end{tabular}

\subsection{Causal Relationship Between ROA, GDPR, EXCR, INFLR and INTR}

In macroeconomic analysis, causality test is common tool used in to check if causality exists or otherwise, between any two variables; From the table 8 below, it shows all of the pvalues are greater than the significant levels of $5 \%$ and $10 \%$, suggesting that causality does not run from the macroeconomic variables (GDPR, EXCR, INFLR and INTR) to Bank performance (ROA) within the period of the study.

Table 8. Pairwise Granger Causality Test Results.

\begin{tabular}{llll}
\hline Pairwise Granger Causality Tests & & & \\
\hline Null Hypothesis: & Obs & F-Statistic & Prob. \\
\hline GDPR does not Granger Cause ROA & 28 & 0.18993 & 0.8283 \\
ROA does not Granger Cause GDPR & & 0.28454 & 0.7550 \\
EXCR does not Granger Cause ROA & \multirow{2}{*}{28} & 0.08813 & 0.9160 \\
ROA does not Granger Cause EXCR & & 0.02880 & 0.9716 \\
INFLR does not Granger Cause ROA & \multirow{2}{*}{28} & 0.39114 & 0.6807 \\
ROA does not Granger Cause INFLR & & 0.10069 & 0.9046 \\
\hline
\end{tabular}

\begin{tabular}{llll}
\hline Pairwise Granger Causality Tests & & & \\
\hline Null Hypothesis: & Obs & F-Statistic & Prob. \\
\hline INTR does not Granger Cause ROA & 28 & 0.96954 & 0.3942 \\
ROA does not Granger Cause INTR & & 0.18863 & 0.8294 \\
\hline
\end{tabular}

Next is the VAR analysis.

\subsection{Unrestricted VAR Analysis}

\subsubsection{VAR Lag Length Selection}

As statistically established, the first step in estimating the VAR model is to determine the lag length for a parsimonious specification. To achieve this, the researchers engaged all the automatic lag selection criteria as shown below; The VAR lag order selection criteria on table 9 reveals that lag length of 1 is selected at $5 \%$ level based on sequential modified LR test statistic, Final prediction error (FPE), Akaike information criterion (AIC), and Hannan-Quinn information criterion (HQ), indicating that VAR (1) specification is the parsimonious model and the plausible description of the data used. The researchers confidently proceed to estimate a VAR 
(1) model for the relationship between the deposit money banks' performance and macroeconomic variables.

Table 9. VAR Lag Order Selection Criteria.

\begin{tabular}{|c|c|c|c|c|c|c|}
\hline \multicolumn{7}{|c|}{ VAR Lag Order Selection Criteria } \\
\hline \multicolumn{7}{|c|}{ Endogenous variables: LNROA LNGDPR LNEXCR LNINFLR LNINTR } \\
\hline Lag & $\log L$ & LR & FPE & AIC & SC & HQ \\
\hline 0 & -83.98563 & NA & 0.003299 & 8.474822 & 8.723518 & 8.528796 \\
\hline 1 & -27.82648 & $80.22736^{*}$ & $0.000184 *$ & $5.507284 *$ & $6.999459 *$ & $5.831124 *$ \\
\hline
\end{tabular}

* indicates lag order selected by the criterion.

LR: sequential modified LR test statistic (each test at $5 \%$ level).

FPE: Final prediction error.

AIC: Akaike information criterion.

SC: Schwarz information criterion.

HQ: Hannan-Quinn information criterion.

\subsubsection{Residual Diagnostic Test}

The researchers proceed with residual diagnostic tests; VAR Residual Serial Correlation LM, VAR Residual Heteroscedasticity, Inverse roots of Autoregressive Characteristic Polynomial and Normality; In Table 10 below, VAR Residual Serial Correlation LM Tests P-value is 0.1989, which an indication of rejection of the null hypothesis, indicating evidence no serial correlation.

Table 10. VAR Residual Serial Correlation LM Tests.

\begin{tabular}{|c|c|c|c|c|c|c|}
\hline \multicolumn{7}{|c|}{ VAR Residual Serial Correlation LM Tests } \\
\hline Lag & LRE* stat & Df & Prob. & Rao F-stat & Df & Prob. \\
\hline 1 & 32.18623 & 25 & 0.1527 & 1.417330 & $(25,23.8)$ & 0.1989 \\
\hline
\end{tabular}

Again, Table 11 shows that Chi-sq is 170.6251 with Pvalue of 0.11193 . This is sufficient evidence suggesting of homoscedasticity of the model.

Table 11. VAR Residual Heteroscedasticity Test.

\begin{tabular}{lll}
\hline Joint test: & & \\
\hline Chi-sq & Df & Prob. \\
\hline 170.6251 & 150 & 0.1193 \\
\hline
\end{tabular}

VAR Residual Heteroskedasticity Tests (Levels and Squares).

\subsubsection{Stability Check}

To examine the stability of the estimated VAR (1) model, the researchers plots the inverted roots in relation to unit circle. It is statistically known that the estimated VAR model is stable if all the inverted points are inside the unit circle as shown below; Figure 2 below shows the inverse roots of the characteristics AR polynomial. It indicates that all roots fall or lie within the unit imaginery circle (modulus), an indication that VAR (1) model is stable.
Inverse Roots of AR Characteristic Polynomial

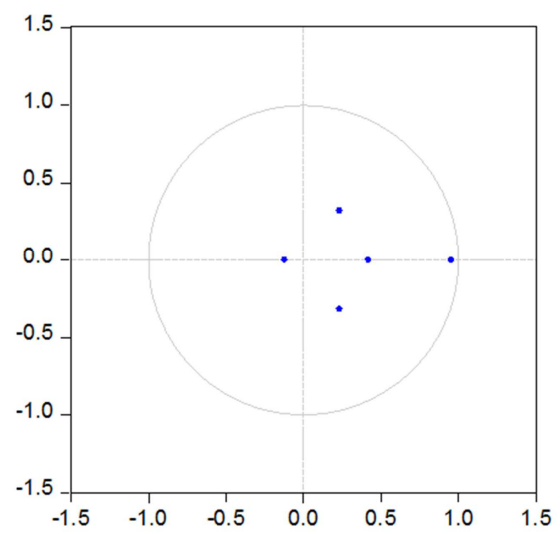

Figure 2. Graphical Representation of Inverse roots of AR Characteristic Polynomial.

\subsubsection{Error Correction and Long run Causality Test}

Having established that the variables are cointegrated, there is likelihood of adjustment from short run to long run equilibrium. That is to say that errors encountered in the short run can be corrected or adjusted in the long run. To achieve the consistency, the researchers estimated the model with Vector Error Correction Estimates as shown below;

The analysis in table 12 below reveals that error correction equation (CointEq1) has coefficient of -0.255452 and $t-$ statistic of -2.41389 . That means error correction parameter is negative and significant, satisfying the apriori expectation (condition), hence, significant. The speed of adjustment is $25.5 \%$. The cointegration already established is confirmed. That means short term errors can be corrected in the long run with annual speed of adjustment $25.5 \%$.

Table 12. Vector Error Correction Estimates.

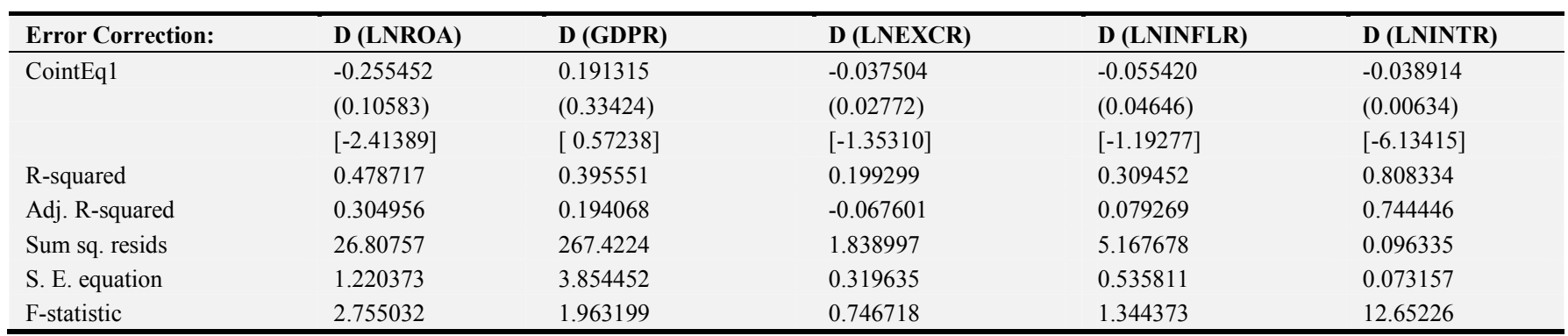




\subsubsection{Short Run Causality Test}

To examine the short run causality implications of the variables, the researchers adopted VEC Granger Causality/Block Exogeneity Wald Test as depicted below;

Table 13 below reveals that $p$-values all the macroeconomic variables (GDPR, EXCR, INFLR and INTR) are insignificant at $5 \%$ and $10 \%$, also p-values of 'All' is insignificant. This is confirmed evidence that each and jointly the macroeconomic variables do not cause ROA in the short run and long run. In sum, all macroeconomic variables (GDPR, EXCR, INFLR and INTR) jointly do not cause bank performance (ROA).

Table 13. VEC Granger Causality/Block Exogeneity Wald Test.

\begin{tabular}{llll}
\hline \multicolumn{2}{l}{ Dependent variable: LNROA } & & \\
\hline Excluded & Chi-sq & df & Prob. \\
\hline LNGDPR & 1.414786 & 2 & 0.4929 \\
LNEXCR & 2.692130 & 2 & 0.2603 \\
LNINFLR & 2.165200 & 2 & 0.3387 \\
LNINTR & 3.656787 & 2 & 0.1607 \\
All & 9.740818 & 8 & 0.2837 \\
\hline
\end{tabular}

\subsubsection{Impulse Response of ROA to Its Own Shock and Shocks from GDPR, EXCR, INFLR and INTR}

As seen from the previous analysis, all the macroeconomic variables (GDPR, EXCR, INFLR and INTR) contemporaneously and inter-temporally do not jointly cause or relate banks' performance (ROA), hence need to examine the shocks or innovations of ROA from itself and from GDPR, EXCR, INFLR and INTR. Again, examine the dynamic impacts or shocks of macroeconomic variables variations on banks' performance. This is achieved with impulse responses and variance decomposition as shown below; From figure 3, the impulse response function shows one time shock to the variables. It shows that ROA responds positively to own shock from first year to fourth year and fades away slightly to the threshold until the tenth year. ROA responds insignificantly from the shocks of all the macroeconomic variables (GDPR, EXCR, INFLR and INTR).

Response to Cholesky One S.D. (d.f. adjusted) Innovations \pm 2 S.E.

Response of LNROA to LNROA

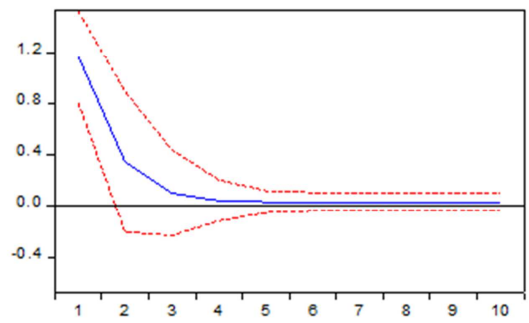

Response of LNROA to LNEXCR

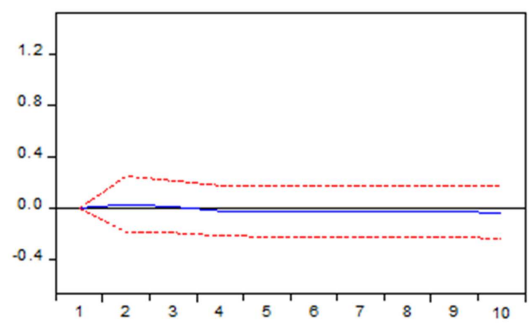

Response of LNROA to LNINTR

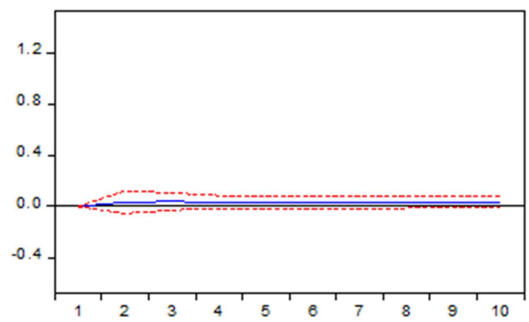

Response of LNROA to LNGDPR

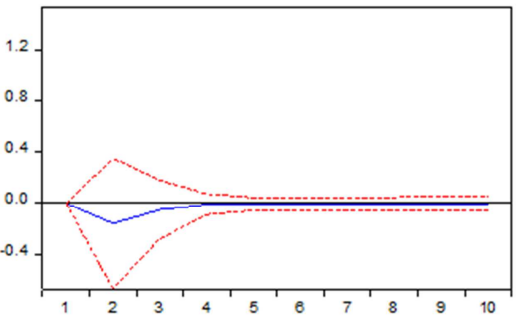

Response of LNROA to LNINFLR

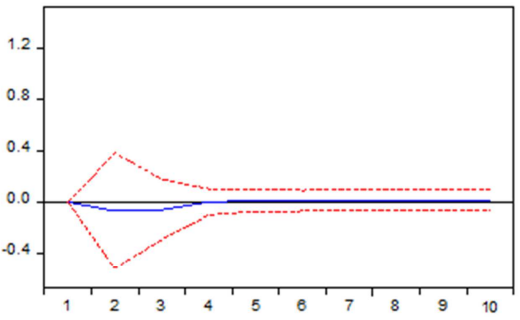

Figure 3. Graph depicting Responses of ROA to Shocks.

\subsubsection{ROA Own Shocks and Shocks from GDPR, EXCR, INFLR and INTR -Variance Decomposition}

Table 14 below, own shock caused 100 percent variations in the first period and diminished to $62.6 \%$ in the 10 tenth.
That suggests that own shock exerted huge influence in the cause of variation on bank performance, whereas all the macroeconomic variables (GDPR, EXCR, INFLR and INTR) diminutively cause the variations in the bank performance (ROA) with range of $0 \%$ to $15 \%$ variations. 
Table 14. Variance Decomposition Results.

\begin{tabular}{lllllll}
\hline Period & S. E. & LNROA & GDPR & LNEXCR & LNINFLR & LNINTR \\
\hline 1 & 1.129857 & 100.0000 & 0.000000 & 0.000000 & 0.000000 & 0.000000 \\
2 & 1.165454 & 94.07242 & 0.886550 & 0.106531 & 0.171476 & 4.763026 \\
3 & 1.296816 & 80.67783 & 2.855486 & 3.352329 & 4.785098 & 8.329254 \\
4 & 1.314272 & 78.93515 & 3.381570 & 3.880604 & 4.659878 & 9.142798 \\
5 & 1.366100 & 73.12195 & 3.131610 & 3.683044 & 10.83325 & 9.230151 \\
6 & 1.410589 & 68.72859 & 3.356200 & 5.888702 & 13.31593 & 8.710581 \\
7 & 1.442091 & 66.43236 & 3.213004 & 7.992635 & 13.08683 & 9.275171 \\
8 & 1.454307 & 65.34653 & 3.203515 & 8.392889 & 13.07291 & 9.984155 \\
9 & 1.472299 & 63.77442 & 3.190756 & 8.314562 & 14.50073 & 10.21954 \\
10 & 1.486909 & 62.62269 & 3.242520 & 8.180411 & 15.92410 & 10.03028 \\
\hline
\end{tabular}

\section{Conclusions and Recommendations}

This study, macroeconomic variables and the performance of deposit money banks in Nigeria with all the finametric tools, made shocking revelations; that macroeconomic variables are not enough to explain the variations in the bank performance. As a result, went further to show that all the macroeconomic variables have no significant relationship with bank performance. It was also observed that severally, each and jointly, the macroeconomic variables do not cause bank performance both in the short run and long run. Again, it observed that bank performance responds insignificantly to the shocks of all the macroeconomic variables. Unarguably, the findings in this study are in total agreement with the outcome of Khrawish and Al-sa'di [28] that macroeconomic variables; GDP growth, interest rate, inflation rate, money supply and exchange rate are not in control of the banks' management. Sequel to that, the researchers advocate that deposit money banks in Nigeria with inherent discretionary policy be proactive to the monetary and fiscal policies of regulatory authorities in order to enhance their performance.

\section{References}

[1] Aburime, T. U. (2009). Determinants of banks profitability: Macroeconomic evidence from Nigeria. International Economics and Financial Journal, 4 (1/2), 69-91.

[2] Acaravci, S. K. \& Calim, A. E. (2013). Turkish banking sector's profitability factors. International Journal of Economics and Financial Issues, 3 (1), 27.

[3] Addae, A. A., Nyarko-Baasi, M. \& Tetteh, M. C. (2014). Effect of exchange rate movements in Ghanian banks. Journal of Finance and Accounting, 3 (3), 62-71.

[4] Adegbaju, A. A. \& Olokoyo, F. O (2008). Recapitalization and banks' performance: A case study of Nigerian banks. African Economic and Business Review, 6 (1): 1-17

[5] Adler, M. \& Dumas, B. (1980). The exposure of long term foreign currency bonds. Journal of Fiinancial and Quantitative Analysis, 15 (4), 973-994.

[6] Akani, H. W., Nwana, I. \& Mbachu, A. (2016). Effects of selected macroeconomic variables on commercial banks performance in Nigeria. IIARD International Journal of Banking and Finance, 2 (3), 34-75.

[7] Alaba, O. B. (2002). Exchange rate uncertainty and foreign direct investment in Nigeria. Trade Policy Research and Training Programme (TPRTP); Department of Economics, University of Ibadan, Ibadan, Nigeria. SSRN: https://ssrn.com/abstract=2793530. Retrieved 20/02/2020.

[8] Asutay, M. \& Izhar, H. (2007). Estimating for profitability of Islamic banking: Evidence from bank Muamatat Indonesia. Review of Islamic Economics, 11 (2), 17-29.

[9] Athanasoglous, P. P., Brissimis, S. N. \& Delis, M. D. (2005). Bank-specific, industry-specific and macroeconomic determinants of bank profitability. MPRA Working Paper No. 25.

[10] Basher, A. H. M. (2003). Determinants of profitability in Islamic banks: Some evidence from the Middle East. Islamic Economic Studies, 11 (1), 31-57.

[11] Bolt, W., DeHaan, L., Hoeberichits, M., Van Oordt, M. R. \& Swank, J. (2012). Bank profitability during recessions. Journal of Banking and Finance, 36 (9), 2552-2564.

[12] Brooks, C. (2008). Introductory econometric for finance. New York, Cambridge University Press.

[13] Calza, A., Munrieque, M. \& Sousa, J. (2006). Credit in the Euro area: An empirical investigation using aggregate data. The Quarterly Review of Economics and Finance, 4 (2), 211-226.

[14] Chamberlin, S., Howe, J. S. \& Popper, H. (1997). The exchange rate exposure of US and Japanese banking institutions. Journal of Banking and Finance, 21 (6), 871-892.

[15] Combey, A. \& Togbenou, A. (2017). The bank sector performance and macroeconomics environment: Empirical evidence in Togo. International Journal of Economics and Finance, 9 (2), 180-188.

[16] Demirgue-Kunt, A. \& Huizinga, H. (1999). Determinants of commercial bank interest margins and profitability: Some international evidence. The World Bank Economic Review, 13 (2), 379-408.

[17] Diamond, D. W. \& Dybvig, P. H. (1983). Bank runs, deposit insurance and liquidity. The Journal of Political Economy, 401-419.

[18] Engel, P. \& Granger, C. (1987). Co-integration and error correction: representation, estimation, and testing, Journal Econometrica, 55, 251-276.

[19] Enyioko, N. (2012). Impact of interest rate policy and performance of deposit money banks in Nigerian. Global Journal of Management and Business Research, 2 (1), 23-30. 
[20] Francis, M. E. (2013). Determinants of commercial bank profitability in Sub-Saharan Africa. International Journal of Economics and Finance, 5 (9), 134.

[21] Granger. C. W. J (1969). Investigating causal relations by econometric models and cross-spectral methods. Journal of econometrica, 37 (3). 424-438.

[22] Hunjra, A. I., Chani, M. I., Shahzad, M., Farooq, M. \& Khan, K. (2014). The impact of macroeconomic variables on stock prices in Pakistan. International Journal of Economics and Empirical Research, 2 (1), 13-21.

[23] Isaac, I. C. (2015). Assessing the impact of exchange rate risk on banks performance in Nigeria. Journal of Economics and Sustainable Development, 6 (6), 1-13.

[24] Jimenez, G., Ongena, S., Peydro-Alcalde, J. I. \& Saurina, J. (2009). Credit supply: Identifying balance sheet channels with loan applications and granted loans. CEPR Discussion Paper Series 7655.

[25] Johansen, S. (1998). Statistical analysis of co-integration vectors. Journal of Economic Dynamics and Control 12, 231-254.

[26] Jung, C. \& Seldon, B. (1995). The macroeconomic relationship between advertising and consumption. Southern Economic Journal, 61 (3), 577-58.

[27] Khrawish, H. A. (2011). Determinants of commercial banks performance: evidence from Jordan. International Research Journal of Finance and Economics, 81, 148-159.

[28] Khrwish, H. A. \& Al-Sa'di, N. M. (2011). The impact of Ebanking on bank profitability: Evidence from Jordan. Middle Eastern Finance and Economics, 13, 142-158.

[29] Koirala, J. (2009). Stock market development and economic growth: Evidence from underdeveloped nation (nepal). A research proposal submitted to faculty members, economics department, Tribluva University, Nepal. August, Retrieved from http://www.freestonesoft.com/41955. Retrieved on 4/20/2020.

[30] Luehrman, T. A. (1991). Exchange rate changes and the distribution of industry value. Journal of International Business Studies, 22 (4), 619-649.

[31] Luft, L. \& Omarkhil, H, (2018). Impact of macroeconomic factors on banking profitability. International Finance and Banking, 5 (1), 44-69.

[32] Moshood, O. \& Ashraf, M. (2012). Bank specific and macroeconomic profitability determinants of Islamic banks: The case of different countries. Qualitative Research in Financial Markets, 4 (2/3), 255-268.

[33] Mukhtar T, M. Z., \& Ahmed, M. (2007). An empirical investigation for twin deficits hypothesis in Pakistan. Journal of Economic Corporation, 28 (4), 63-80.
[34] Okoye, V. \& Eze, O. R (2012). Effect of bank lending rate on the performance of Nigerian deposit money banks. International Journal of Business and Management Review, 1 (1): 34-43.

[35] Osamuonyi, I. O. \& Michael, C. I. (2014). The impact of macroeconomic variables on the profitability of listed commercial banks in Nigeria. European Journal of Accounting, Auditing and Finance Research, 2 (10), 85-95.

[36] Osuagwu, E. S. (2014). Determinants of banks' profitability in Nigeria. International Journal of Economics and Finance, 6 (12), 46.

[37] Pradhan, R. S. \& Shrestha, R. (2016). Impact of bank specific and macroeconomic variables on the performance of commercial banks of Nepal.

[38] Revel, J. (1979). Inflation and financial institution. Financial Times. www.googlescholar.org. Retrieved 26/2/2020.

[39] Saad, W, \& El-Moussawi, C. (2012). The determinants of net interest margins of commercial banks in Lebanon. Journal of Money, Investment and Banking, 23, 118-132.

[40] Sayedi, S. (2013). Bank specifc, industrial specific and macroeconomic determinants of banks profitability $\mathrm{n}$ Ngeria. Journal of Finance, www.googlescholar.org. retrieved, 6/4/2020.

[41] Scott, A. O. \& Ovuefeyen, E. J. (2014). Effects of economic openness and inflation on commercial banks' profitability: Panel data evidence from Nigeria, post-banking sector consolidation. European Journal of Business and Management, 6 (30).

[42] Simiyu, C. N. \& Ngile, L. (2015). Effects of macroeconomic variables on profitability of commercial banks listed in the Nairaobi securities exchange. International Journal of Economics, Commerce and Management. www.researchgate.org, retrieved 11/3/2020. SSRN: https://ssrn.com/abstract $=2793530$. Retrieved 13/02/2020.

[43] Sufian, F. \& Habibullah, M. S. (2010). Does economic freedom fosters banks' performance? Panel evidence from Nigeria. Journal of Contemporary Accounting and Economics, $6(2), 77-94$.

[44] Tan, Y. \& Floros, C. (2012). Bank profitability and inflation: The case of China. Journal of Economics Studies, 39 (6), 675-696.

[45] Trujillo-Pounce, A. (2013). What determines the profitability of banks: Evidence from Spain? Journal of Accounting and Finance, 53 (2), 561-586.

[46] Wikipedia (2020) General Method Moments (GMM). Available at www.wikipedia.org. Retrieved 23/3/2020. 